\title{
AKTÉŘI ÚZEMNÍHO ROZVOJE VE MĚSTĚ BRNĚ: ZAMĚŘENO NA DEVELOPERY VÝZNAMNÝCH NÁKUPNÍCH CENTER
}

\author{
Zdeněk Dvořák
}

\begin{abstract}
Brno is the second largest city in the Czech Republic. At the same time, it is a city that, by its nature, represents an important commuting center not only for work and schools, but also for services. The construction of shopping centers is no longer a matter of greenfield construction - which is particularly suited to cities, because in these cases, a revitalization of the site is desirable. This article builds on previous articles dealing with apartment and office construction, focusing on the most important shopping center projects, exploring their basic economic and spatial aspects. The article will also focus on a brief comparison of this segment within the Czech and Slovak Republics in terms of past, current and future development.
\end{abstract}

Keywords: shopping center, developer, city of Brno, territorial development

\section{Úvod}

Za předchůdce nákupních center lze považovat obchodní domy, jejichž koncept znamenal skutečnou revoluci ve způsobech nakupování. Jedním z prvních na světě vủbec byl Le Bon Marché (v překladu "Dobrý trh"), založený roku $1838 \mathrm{v}$ Paříži. Obchodní domy a pozdější obchodní či nákupní centra se staly jedním z nástrojů hlubších společenských a ekonomických změn, jež znamenaly obrat od nákupů z „nutnosti“ k nákupům pro zábavu (Schiffman, Kanuk, 2004). Obchodní domy byly od druhé poloviny 19 . století poprvé otevřeny pro všechny společenské vrstvy, přičemž zákazníci se mohli volně procházet, vybírat či pouze prohlížet zboží (Klaffke, 2003; Coleman, 2006). K rozšiření konzumního způsobu života pomohla také rostoucí kvantita i kvalita sériově vyráběného zboží a jeho dostupnost širším společenským vrstvám (Timothy, 2005), což v modernější podobě setrvalo prakticky dodnes.

Koncept suburbánních nákupních center se vyvinul až po 2 . světové válce $\mathrm{v}$ USA. V polovině 50. let se objevují již plně zastřešená/uzavřená nákupní centra, na rozdíl od dřívější formy open air prostoru, a začínají stahovat obchodníky i zákazníky z městských center (Scott, 1970/2008). Sedmdesátá a osmdesátá léta pak byla v USA ve znamení omezování negativních vlivů developerské výstavby nákupních center „na zelené louce“ na obchodní funkci center měst. Zároveň však vznikl nový koncept $\mathrm{s}$ názvem mega mall, umist’ovaný na okraje měst v návaznosti na rozsáhlé městské aglomerace (Buttler, 1991). 
V Evropě vznikala nákupní centra s odstupem asi 10 let od USA. Byla menší a nedošlo zde k tak rozsáhlé výstavbě na zelené louce, ani k vylidnění center jako v USA (zejména s ohledem na historicky odlišnou morfogenetickou strukturu měst, suburbánní zástavbu a regulaci městské zástavby). V 60. letech se v západní a severní Evropě stavěla nákupní centra na zelené louce v blízkosti velkých dálničních křižovatek, přičemž se jednalo o jednopodlažní stavby s přízemním parkovištěm (Scott, 1970/2008; Szczyrba, 2005). Později si developeři uvědomili nákupní sílu a možnosti vnitřního města a výstavba na zelené louce se přesunula do intravilánů měst a do satelitních městeček. Ohledy byly brány i na zákazníky nevlastnící auto. Centra byla dvoupodlažní a uvnitř vznikaly hotely, zóny volného času a jiná zařízení, která mohla být využita i jiným způsobem než jen jako prodejní jednotka (Guy, 1998b).

V další etapě $\mathrm{v}$ osmdesátých a devadesátých letech jsou preferována většinou centra o střední velikosti prodejní plochy v rozmezí $20-40$ tis. $\mathrm{m}^{2}$ (Szczyrba, 2005). Vývoj pokračoval v 90. letech zejména modernizací a rozšiřováním již postavených nákupních center. Zatímco v ekonomicky vyspělých zemích byly spíše vyplňovány mezery na trhu a nebyl kladen důraz na pouhý růst pronajímatelné plochy, v tranzitních zemích střední a později i východní Evropy nastal téměř nekontrolovatelný developerský boom (Nagy, 2001; Mitríková, 2008; Trembošová, 2010; Kunc a kol., 2012b, 2016; Dębek, 2015; Križan a kol., 2016; Trembošová a kol., 2016 a mnoho dalších).

\section{Teoreticko-metodická východiska}

Klasifikovat nákupní centra je poměrně složité, neexistuje totiž jednotná shoda na kritériích či kategoriích třídění. Lze je klasifikovat z několika hledisek, např. podle velikosti, uspořádání, vlastnictví, účelů nákupních cest do nákupních center nebo klasifikace na základě centrality v rámci obslužných funkcí. Velmi důležitým třídicím prvkem je samotná lokalizace nákupních center; zde pak rozlišujeme tzv. edge-of-centre, out-of-centre a out-of-town nákupní centra (Guy, 1998a; England, 2000; Lambert, 2006).

Zjednodušeně lze tedy nákupní centra rozdělit na ta, která fungují ve vnitřní funkční struktuře měst, a centra $\mathrm{v}$ periferní poloze či v těsné blízkosti měst, což je také jedním ze základních kritérií při rozhodování developerů o investici. Prvně jmenovaná centra svojí nabídkou i cenou zboží a služeb odrážejí faktor polohové renty a výši vstupních nákladů - jedná se o vnitroměstská nákupní centra vyšší cenové úrovně vzniklá často $\mathrm{v}$ procesu revitalizace opuštěných či jinak deprimujících ploch bývalých areálů továren a vlakových nádraží (Kok, 2007; Kunc a kol., 2012a). Matlovič (2001) či Šveda, Križan (2012) považují výstavbu nákupních center v blízkosti zastavěných ploch uvnitř města za typický projev komercionalizace. Na druhou stranu hlavní výhodou lokalizace periferních nákupních center je dostatek místa pro rozvoj obchodních i neobchodních ploch 
včetně těch relevantních pro fungování nákupních center jako např. dopravní infrastruktura, parkovišstě apod. (Kunc et al., 2012c).

Nákupní centra tedy nejen generují široký vnější i vnitřní nákupní spád, ale svou nabídkou obchodních i neobchodních funkcí také vyvolávají zvýšený cestovní ruch směrem do míst jejich lokací, což berou na zřetel i developeři. Svou podstatou se tak nákupní centra $\mathrm{v}$ dnešní době významně podílejí na rozvoji nových forem městského cestovního ruchu a rekreace (Bacsi, 2017; Trembošová a kol., 2017; Novanská a kol., 2018) a zásadním způsobem mění dosavadní pohled na současný městský cestovní ruch, resp. na cesty do měst za účelem nakupování (Szczyrba, 2002; Timothy, 2005; Spilková, 2012).

Z hlediska provozování nákupních center a jejich úspěchu je velmi důležitý mix nájemců působících v objektu centra (Kunc a kol., 2016), což už je ovšem mimo primární zájem průmyslového developmentu, pokud ovšem není developer zároveň také provozovatelem. Dříve byly páteří nákupních center obchody $\mathrm{s}$ potravinami. S rozvojem decentralizovaných nákupních center nastoupil ale nový trend a mnoho jich začalo fungovat jako společenská a zábavní centra a jako místa setkávání lidí. Začala nabízet celou řadu non-retailových aktivit, jakými jsou rekreační a zábavní zařízení (multikina, různé akce pořádané pro zákazníky $\mathrm{v}$ rámci marketingových aktivit apod.) a provozovny pro sportovní vyžití (fitness, bazény, kluziště a další).

Jak již bylo výše naznačeno, developerské aktivity $\mathrm{v}$ prostředí maloobchodu, resp. konkrétně při výstavbě nákupních center, jsou nutně spjaty jak $\mathrm{s}$ prostorovými analýzami nákupního spádu a nákupní oblasti, tak $\mathrm{s}$ marketingovými strategiemi a územním plánováním (Teller, Elms, 2012; Wood, Reynolds, 2012; Bilková a kol., 2017). Většina obyvatel vyspělého, ale i rozvojového světa žije ve městech, proto je důležité podporovat výstavbu občanské vybavenosti $\mathrm{v}$ intravilánu i extravilánu města, ale $\mathrm{s}$ ohledem na kvalitu života a udržitelnost městského prostředí (Ardeshiri a kol., 2018). Kritika ze strany místních obyvatel, ale i zástupců městských samospráv a v neposlední řadě i odborníků - urbanistů a městských plánovačů - se snáší především na obří developerské projekty na zelené louce lokalizované na okrajích měst, v suburbánní zóně (Guy, 1998b; Koželouh, 2010). Takováto výstavba znamená značný zásah do kulturní krajiny a kvality života obyvatel dotčeného území (nová technická a dopravní infrastruktura, vznik nových linek MHD, zvýšení intenzity automobilové dopravy se všemi neduhy, zábor kvalitní půdy a další), a take do rovnováhy maloobchodního prostředí, protože dokáže efektivně zlikvidovat menší obchody nejen ve svém okolí, ale i v centru města (Kunc a kol., 2012a). Řešením by měla být regulace $\mathrm{v}$ podobě nástroje RIA (Retail Impact Assessment), která však není důsledně uplatňována ani v rámci zemí EU; v České republice či na Slovensku např. nebyla dodnes vůbec zavedena (Spilková, 2010; Križan, Lauko, 2014).

Cílem článku je analyzovat nejvýznamnější projekty v oblasti výstavby nákupních center ve městě Brně. Tento příspěvek navazuje na předchozí články, 
které se zabývaly bytovou a kancelářskou výstavbou, a zaměřuje se na nejvýznamnější projekty nákupních center, zkoumá jejich základní ekonomické a prostorové aspekty. Článek se rovněž zaměří na stručnou komparaci tohoto segmentu v rámci České a Slovenské republiky.

\section{Nákupní centra v České republice a na Slovensku}

V České republice existuje okolo devadesáti nákupních center, jejichž výstavba postupně začala $\mathrm{v}$ druhé polovině devadesátých let. Co se týká hlavního umístění těchto center, ze začátku výstavba probíhala zejména na předměstí jednotlivých měst a $v$ převážně většině se jednalo o výstavbu na zelené louce. Postupem času se však situace změnila a $\mathrm{k}$ dnešnímu dni existuje v České republice více jak polovina nákupních center, jejichž výstavba proběhla na území bývalého brownfiledu. Do roku 2005 se prritom jednalo pouze o třináct nákupních center postavených na jinak využívaných územích. Od roku 2006 se pozornost developerů zaměřila také na vnitřní části měst a na dříve zastavěná území - vzniklo zde trricet čtyři nákupních center. Na zelené louce prritom celkově proběhla výstavba pouze deseti nákupních center. Přesto lze konstatovat, že co do významnosti z hlediska nabízených ploch, jsou nákupní centra vystavěná na zelené louce větší ( $62 \%$ celkového objemu pronajímatelné plochy).

$\mathrm{Na}$ Slovensku je situace velmi podobná. $Z$ padesáti šesti nákupních center vzniklo třicet výstavbou na zelené louce, do roku 2007 se jednalo o sedmnáct nákupních center. Na dřive využívaných územích to pak bylo pouze sedm nákupních center. Stejně jako v ČR se až na výjimky jednalo o předměstské lokality. Mezi roky 2004 až 2008 se situace postupně obrací a developeři na Slovensku od tohoto období realizují své projekty více v lokalitách, které byly již nějakým způsobem $\mathrm{v}$ minulosti využívány (téměř $2 / 3$ projektů) (Trembošová, 2012; Križan a kol., 2017).

\section{Nákupní centra v Brně}

Město Brno je druhé největší město v České republice. Vzhledem k počtu obyvatel, kteří zde žijí (379 tis.), případně do města přijíždějí za prací, do škol či za službami, rovněž vyžaduje dostatečnou nabídku služeb. V rámci města Brna bylo analyzováno celkem sedm nákupních center.

\section{Avion Shopping park}

Toto nákupní centrum bylo otevřeno v roce 1998. Nachází na jihu měst Brna $\mathrm{v}$ těsné blízkosti dálnic D1 a D2 a je obslouženo jednak městskou hromadnou dopravou, tak autobusovou dopravou zdarma. Developerem, vlastníkem a provozovatelem tohoto nákupního centra je Inter IKEA Centre Group. Samotné nákupní centrum se skládá $\mathrm{z}$ více budov, ve kterých nalezneme padesát pět 
provozoven $-\mathrm{z}$ toho osm restaurací/kaváren (Avion shopping park, 2018). Hrubá pronajímatelná plocha tohoto nákupního centra má $60137 \mathrm{~m}^{2}$. V roce 2017 se zde mělo začít s rozšiřrováním nákupního centra za 220 mil. Kč o 15 tis. $\mathrm{m}^{2}$. Stavba měla dle původních předpokladů hotova $\mathrm{v}$ roce 2020 . Prozatím se však dostavba $\mathrm{v}$ lokalitě nerealizuje (STOPRO Architects, 2018; Rapco, Nečasová, 2016).

\section{Campus Square}

Jedná se o nejmladší nákupní centrum nacházející se na území města Brna $\mathrm{v}$ blízkosti nemocnice Bohunice, Masarykovy univerzity a administrativních budov, kde sídlí napřr. společnost Kiwi. V samotné budově se nachází osmdesát provozoven, z toho sedmnáct restaurací/kaváren (Campus Square, 2018). Dopravní dostupnost městskou hromadnou dopravou této lokality je vzhledem $\mathrm{k}$ vysoké koncentraci osob, které do lokality dojíždějí, poddimenzovaná. Město Brno tak připravuje a v brzké době bude realizovat projekt prodloužení tramvajové trati $\mathrm{z}$ Osové.

\section{Galerie Van̆kovka}

Společně s Velkým Špalíčkem se jedná o další nákupní centrum, které bylo vystaveno $\mathrm{v}$ místech nevyužívaného brownfieldu. Investorem projektu byla společnost ECE a Jižní centrum Brno (Statutární město Brno, 2013). Vzhledem k blízkosti historického centra, dobrého napojení na městkou hromadnou dopravu, se Vaňkovka stala oblíbeným místem, které denně navštíví velké množství návštěvníků. Vaňkovce je částečně vyčítána skutečnost, že se s její realizací nepodařilo v okolí vytvořit živý bulvár. Návštěvníci zde v současné době najdou sto čtyřicet dva provozoven, $\mathrm{z}$ toho dvacet dva restaurací/kaváren (Galerie Vaňkovka, 2018).

\section{NC Královo Pole}

NC Královo Pole se od roku 2004 nachází v severní čísti města Brna dopravně dostupné městskou hromadnou dopravou. Co se týká individuální automobilové dopravy, je centrum umístěno v blízkosti velkého městského okruhu. Nachází se zde devadesát provozoven, z toho jedenáct restaurací/kaváren (NC Královo Pole, 2018). V roce 2017 prodal britský investor Aerium nákupní centrum investiční skupině CPI zastoupenou společnosti CBRE. Finanční náklady transakce nejsou známy (Gregorová, 2017).

\section{OC Futurum}

Další nákupní centrum, které se nachází v jižní části města Brna v blízkosti dálnice D1 a E461. Návštěvníci centra se sem dostanou městskou hromadnou dopravou a také autobusovou linkou zdarma. $\mathrm{V}$ porovnání $\mathrm{s}$ dalšími nákupními centry se potýká s nižší návštěvností. To by se mohlo změnit nyní - nákupní centrum koupila investiční skupina Trikaya a Opifer, která má v plánu do nákupního centra 
investovat 1 mld. Kč. Do nákupního centra chtějí přivést typy obchodů, které dle investora v Brně chybí (Novák, 2018, ČTK, 2018). V současné době není kapacita nákupního centra zcela naplněna - nachází se zde šedesát provozoven, z toho sedm restaurací/kaváren (OC Futurum Brno, 2018).

\section{Olympia Brno}

I když název nákupního centra nese název Olympia Brno, nachází se větší část nákupního centra na katastru Modřic, které s městem Brnem sousedí. Svou spádovostí však zcela jistě k Brnu patří. Stejně jako nákupní centrum Avion Shopping park Brno se Olympia nachází v blízkosti dálnice D1 a D2, centrum je rovněž dostupné zdarma autobusovou dopravou a městskou hromadnou dopravou. Zároveň se jedná o největší nákupní komplex - dohromady je zde dvě stě deset provozoven, $\mathrm{z}$ toho dvacet pět jsou restaurace/kavárny. Kromě standardních funkcí se zde nachází lezecká stěna, in-line dráha, $v$ zimě kluziště a celoročně provozované kino (Olympia Brno, 2018). Toto nákupní centrum, které vzniklo v roce 1999, bylo postupně rozšiřováno. Hlavním investorem stavby byla společnost Stannifer z Velké Británie a tehdejší investiční náklady na stavbu dosáhly výše 1,2 mld. Kč (Centroprojekt, 2018). Dnes je hodnota tohoto nákupního centra daleko vyšší. V březnu 2017 jej za více než 10 mld. Kč koupila investiční firma Deutsche EuroShop (iDnes.cz., ČTK, 2017).

\section{Velký Špalíček}

Jedná se o jediné nákupní centrum, které se nachází v historickém jádru města Brna. Investorem projektu byla společnost Intercom - hlavní akcionáři UBM a Warimprex (Havlík, 2001). Z nákupních center, které byly podrobeny analýze, se jedná se svou hrubou pronajímatelnou plochou $\left(12800 \mathrm{~m}^{2}\right)$ o nejmenší nákupní centrum. Najdeme zde celkem třicet sedm provozoven, $z$ toho pět jsou restaurace/kavárny. Zároveň je to po Olympii druhé nákupní centrum, kde se nachází kino.

Tab. 1: Nákupní centra v Brně

Table 1: Shopping centers in Brno

\begin{tabular}{|l|r|r|r|r|r|r|}
\hline Název NC & $\begin{array}{c}\text { Rok } \\
\text { otevření }\end{array}$ & $\begin{array}{c}\text { GLA } \\
\left(\mathbf{m}^{2}\right)\end{array}$ & $\begin{array}{c}\text { Počet } \\
\text { provozoven }\end{array}$ & $\begin{array}{c}\text { Počet } \\
\text { parkovací } \\
\text { ch míst }\end{array}$ & $\begin{array}{c}\text { Poloha/ } \\
\text { vystavěno na }\end{array}$ & Kapitál \\
\hline $\begin{array}{l}\text { Avion } \\
\text { Shopping } \\
\text { Park }\end{array}$ & 1998 & 60137 & 55 & 2553 & $\begin{array}{r}\text { předměstí/zelená } \\
\text { louka }\end{array}$ & $\begin{array}{r}\text { zahraniční- } \\
\text { Inter Ikea } \\
\text { Centre } \\
\text { Group }\end{array}$ \\
\hline $\begin{array}{l}\text { Campus } \\
\text { Square }\end{array}$ & 2008 & 20000 & 84 & 620 & $\begin{array}{r}\text { předměstí/zelená } \\
\text { louka }\end{array}$ & $\begin{array}{r}\text { zahraniční- } \\
\text { CBRE } \\
\text { Global } \\
\text { Investos }\end{array}$ \\
\hline $\begin{array}{l}\text { Galerie } \\
\text { Vaňkovka }\end{array}$ & 2005 & 37000 & 142 & 1000 & vnitřní & $\begin{array}{r}\text { zahraniční- } \\
\text { ECE }\end{array}$ \\
\hline
\end{tabular}




\begin{tabular}{|l|r|r|r|r|r|r|}
\hline $\begin{array}{l}\text { NC } \\
\text { Královo } \\
\text { Pole }\end{array}$ & 2004 & 16993 & 90 & 862 & $\begin{array}{r}\text { vnitřní } \\
\text { město/zelená } \\
\text { louka }\end{array}$ & $\begin{array}{r}\text { domací - } \\
\text { CPI }\end{array}$ \\
\hline $\begin{array}{l}\text { OC } \\
\text { Futurum }\end{array}$ & 2001 & 19525 & 60 & 1500 & $\begin{array}{r}\text { předměstí/zelená } \\
\text { louka }\end{array}$ & $\begin{array}{r}\text { kombinace- } \\
\text { Trikaya a } \\
\text { Opifer }\end{array}$ \\
\hline $\begin{array}{l}\text { Olympia } \\
\text { Brno }\end{array}$ & 1999 & 110000 & 210 & 4027 & $\begin{array}{r}\text { předměstí/zelená } \\
\text { louka }\end{array}$ & $\begin{array}{r}\text { zahraničí } \\
\text { Deutsche } \\
\text { EuroShop }\end{array}$ \\
\hline $\begin{array}{l}\text { Velký } \\
\text { Špalíček } \\
\text { Brno }\end{array}$ & 2001 & 12800 & 37 & 82 & jádro/brownfield & $\begin{array}{r}\text { Domácí }- \\
\text { Generali } \\
\text { Velký } \\
\text { Sistorické } \\
\text { s.r.o }\end{array}$ \\
\hline
\end{tabular}

Zdroj: vlastní šetření, 2018

\section{Závěr}

Obchodní zóny $\mathrm{v}$ centrech měst dříve vznikaly bez předešlého plánování (Crosby a kol., 2005), zatímco dnešní nákupní centrum je (resp. mělo by být) předem plánovaným záměrem. Jeho velikost by měla odpovídat velikosti kupní síly ve spádové oblasti, nabízený sortiment by měl být dostatečně atraktivní, aby přilákal poptávku (Teller, 2008; Križan a kol., 2016; Teller a kol., 2016). V České republice a $\mathrm{s}$ menším odstupem $\mathrm{i} \mathrm{v}$ dalších postsocialistických zemích střední Evropy se nákupní centra etablovala až ve 2 . polovině 90 . let a jejich skutečný rozmach nastal až v minulém desetiletí, tedy s více než čtyřicetiletým odstupem za ekonomicky vyspělou Evropou (Trembošová, 2010; Kunc a kol., 2012a; Križan a kol., 2017).

Developerské aktivity $\mathrm{v}$ segmentu nákupních center zaznamenaly $\mathrm{v}$ posledních dvou dekádách také významný prostorový, funkční i ekonomický posun. Výstavba nákupních center neprobíhá pouze na zelené louce a na předměstí jednotlivých měst, ale čím dál častěji jsou tyto projekty lokalizovány do vnitřní části měst, kde dochází k revitalizacím nevyužívaných území.

Zároveň lze konstatovat, že výstavba nových nákupních center se postupně zpomaluje (Mulíček, Osman, 2018). Dochází a jsou v plánu spíše rozšiřování stávajících nákupních center. Tyto změny souvisí např. s úbytkem volných ploch pro výstavbu nových nákupních center a také se vstupy nových investorů do stávajících nákupních center. Dle dostupných informací je v plánu rekonstruovat např. Olympii v Teplicích či Mladé Boleslavi, Forum Liberec, OC Karviná a další (Svatošová, 2018). Na Slovensku se plánuje rovněž rozšiřování stávajících nákupních center (napřr. Mirage SC, Eurovela Galleria, atd.), ale také otevření nových nákupních center, kde k největším bude patřit bratislavská Stanica Nivy (Suchý, 2017). V následujících letech tak budeme zejména v ČR (na Slovensku s časovým zpožděním) sledovat, zda se tento trend skutečně potvrdí a developeři se spíše zaměří na rozšiřování nákupních center. 


\section{Poděkování}

Př́spěvek byl zpracován v rámci projektu Města, obce, regiony: management, procesy a interakce $v$ teorii a praxi (MUNI/A/0994/2017).

\section{Literatúra}

ARDESHIRI, M. - WILLIS, K. - ARDESHIRI, A. 2018. Exploring preference homogeneity and heterogeneity for proximity to urban public services. In Cities. ISSN 0264-2751, 2018, vol. 81, pp. 190-202.

AVION SHOPPING PARK. Obchody a služby. brno.avion.cz. [online]. IKEA Centres A/S, 2018. [cit. 10. 9. 2018]. Dostupné na internete: https://www.brno.avion.cz/cs-cz/stores.

BACSI, Z. 2017. Tourism and diversity. In Deturope. ISSN 1821-2506, 2017, vol. 9, no. 2, pp. 25-57.

BILKOVÁ, K. - KRIŽAN, F. - BARLÍK, P. - HORŇÁK, M. - BARLÍK, P. KITA, P. 2017. Comparing two distance measures in the spatial mapping of food deserts: The case of Petržalka, Slovakia. In Moravian Geographical Reports. ISSN 1210-8812, 2017, vol. 25, no. 2, pp. 95-103.

BUTLER, R. W. 1991. West Edmonton Mall as a Turist Atraction. In Canadian Geographer. ISSN 1541-0064, 1991, vol. 35, no. 3, pp. 287-295.

CAMPUS SQUARE. Obchody. campusbrno.cz. [online]. Campus Square, 2018. [cit. 10. 9. 2018]. Dostupné na internete: https://www.campusbrno.cz/cs/ obchody

CENTROPOJEKT. Centrum obchodu a služeb, Olympia i Brno - Modřice. centroprojekt.cz. [online]. Centroprojekt, 2018. [cit. 18. 9. 2018]. Dostupné na internete: https://centroprojekt.cz/reference/centrum-obchodu-a-sluzeb-olympia -i-brno-modrice/.

COLEMAN, P. 2006. Shopping Environments. London: Routledge, 2006. 472 p.

CROSBY, N. - HUGHES, C. - LIZIERI, C. - OUGHTON M. 2005. A message from the oracle: The Land use impact of a major in-town shopping centre on local retailing. In Journal of Property Research. ISSN 1466-4453, 2005, vol. 22 , no. 2-3, pp. 245-265.

ČTK. Developer Trikaya koupil pražský obchodní dům Řepy a podíl v brněnském Futuru za více než půl miliardy. byznys.ihned.cz. [online]. 5. 3. 2018. [cit. 10. 9. 2018]. Dostupné z: https://byznys.ihned.cz/c1-66068940-developer-trikayakoupil-prazsky-obchodni-dum-repy-a-podil-v-brnenskem-futuru-za-vice-nezpul-miliardy.

DĘBEK, M. 2015. What Drives Shopping Mall Attractiveness? In Polish Journal of Applied Psychology. ISSN 2354-0052, 2015, vol.13, no. 1, pp. 67-118.

ENGLAND, J. R. 2000. Retail Impact Assessment: A Guide to Best Practice. London: Routledge, 2000. 240 p. ISBN 978-0415216661. 
GALERIE VAŇKOVKA. Obchody. galerie-vankovka.cz. [online]. ECE Projektmanagement GmbH \& Co. KG, 2018. [cit. 10. 9. 2018]. Dostupné z: https://www.galerie-vankovka.cz/obchody/vse/.

GREGOROVÁ, L. NC Královo Pole má nového majitele In centrumnews.cz. [online]. 19. 8. 2017. [cit. 11. 9. 2018]. Dostupné z: http://www.centrumnews.cz/nc-kralovo-pole-ma-noveho-majitele.

GUY, C. M. 1998a. Classifications of Retail Stores and Shopping Centres: Some Methodological Issues. In GeoJournal. ISSN 03432521, 1998, vol. 45, no. 4, pp. 255-264.

GUY, C. M. 1998b. Controlling new retail spaces: The impress of planning policies in western Europe. In Urban Studies. ISSN 0042-0980, 1998, vol. 35, no. 5-6, pp. 953-979.

HAVÍK R. Velký Špalíček v centru Brna. stavebne-forum.sk. [online]. 15. 8. 2001. [cit. 15. 9. 2018]. Dostupné na internete: http://www.stavebneforum.sk/sk/article/980/velky-spalicek-v-centru-brna/.

iDNES.cz, ČTK. Největší nákupní centrum v Brně mění majitele, Olympii kupují Němci. ekonomika.idnes.cz. [online]. 9. 3. 2017. [cit. 6. 9. 2018]. Dostupné z: https://ekonomika.idnes.cz/olympia-brno-prodej-048/ekonomika.aspx?c=A170309_112149_ekonomika_jj.

KLAFFKE, P. 2003. Spree: A Cultural History of Shopping. Vancouver: Arsenal Pulp Press, 2003. 256 p. ISBN 978-1551521435.

KOK, H. J. 2007. Restructuring retail property markets in Central Europe: Impacts on urban space. In Journal of Housing and the Built Environment. ISSN 15737772, 2007, vol. 22, no. 1, pp. 107-126.

KOŽELOUH, J. 2010. Environmentální dopady prostorové expanze velkoplošného maloobchodu v České republice 2003-2009. Brno: Nesehnutí, 2010. 34 s. ISBN 978-80-87217-06-1.

KRIŽAN, F. - LAUKO, V. 2014. Geografia maloobchodu. Úvod do problematiky. Bratislava: Univerzita Komenského, 2014. 196 s. ISBN 978-80-223-3542-3.

KRIŽAN, F. - PAŠKO, M. - BILKOVÁ, K. - BARLÍK, P. - KITA, P. 2016. Heterogeneity of shopping centers' attractiveness in Bratislava. In Geographia Technica. ISSN 2065-4421, 2016, vol. 11, no. 2, pp. 61-68.

KRIŽAN, F. - KUNC, J. - BILKOVÁ, K. - BARLÍK, P. - ŠILHAN, Z. 2017. Development and classification of shopping centers in Czech and Slovak republics: comparative analysis. In Acta Universitatis Carolinae, Geographica. ISSN 0300-5402, 2017, vol. 52, no. 1, pp. 18-26.

KUNC, J. - FRANTÁL, B. - TONEV, P. - SZCZYRBA, Z. 2012c. Spatial patterns of daily and non-daily commuting for retail shopping: case of the Brno city, Czech Republic. In Moravian Geographical Reports. ISSN 1210-8812, 2012, vol. 20, no. 4, pp. 39-54.

KUNC, J. - KRIŽAN, F. - BILKOVÁ, K. - BARLÍK, P. - MARYÁŠ, J. 2016. Are there differences in the attractiveness of shopping centres? Experiences 
from the Czech and Slovak Republics. In Moravian Geographical Reports. ISSN 1210-8812, vol. 24, no. 1, pp. 27-41.

KUNC, J. - TONEV P. - SZCZYRBA, Z. - GREPLOVÁ, Z. 2012a. Perspektivy nákupních center $\mathrm{v}$ České republice $\mathrm{s}$ důrazem na lokalizaci v urbánním prostředí. In Urbanismus a územní rozvoj. ISSN 1212-0855, 2012, roč. 15, č. 2, s. 11-17.

KUNC, J. - TONEV, P. - FRANTÁL, B. - SZCZYRBA, Z. 2012b. Nákupní spád, nákupní chování a nákupní centra: př́íklad brněnské aglomerace (prríspěvek ke studiu denních urbánních systémů). In Sociologický časopis. ISSN 0038-0288, 2012, roč. 48, č. 5, s. 879-910.

LAMBERT, J. 2006. One Step Closer to a Pan-European Shopping Center Standard: Illustrating the New Framework with Examples. In Research Review. 2006, vol. 13, no. 2, pp. 35-40.

MATLOVIČ, R. 2001. Transformačné procesy a ich efekty v intraurbánnych štruktúrach postkomunistických miest. In Premeny Slovenska $v$ regionálnom a didaktickom kontexte. Banská Bystrica: Fakulta prírodných vied UMB, 2001. ISBN 80-8055-583-4, s. 73-81.

MITRÍKOVÁ, J. 2008. Geografické aspekty transformácie maloobchodu a nákupného správania sa na Slovensku (prípadové štúdie z miest Prešov a Košice). Prešov: Prešovská univerzita v Prešove, 2008. 213 s. ISBN 978-808068-922-3.

MULÍČEK, O. - OSMAN, R. 2018. Rhythm of urban retail landscapes: Shopping hours and the urban chronotopes. In Moravian Geographical Reports. ISSN 1210-8812, 2018, vol. 26, no. 1, pp. 2-13.

NAGY, E. 2001. Winners and losers of the transition of city centre retailing in east Central Europe. In European Urban and Regional Studies. ISSN 1461-7145, 2001, vol. 8, no. 4, pp. 340-349.

NC KRÁLOVO POLE. Obchody a služby. krpolenc.cz. [online]. NC KrPole, 2018. [cit. 10. 9. 2018]. Dostupné z: https://www.krpolenc.cz/obchody-a-sluzby

NOVÁK, D. Start-upisté koupili v Brně obchodní centrum. Investují celkem miliardu. E15.cz. [online]. 4. 3. 2018. [cit. 8. 9. 2018]. Dostupné z: https://www.e15.cz/byznys/reality-a-stavebnictvi/start-upiste-koupili-v-brneobchodni-centrum-investuji-celkem-miliardu-1344098.

NOVANSKÁ V. - BENOVÁ, A. - GEGHAMYAN, S. 2018. Možnosti rekreácie $\mathrm{v}$ meste Bratislava na základe percepcie miestneho obyvatelstva. In Geographia Cassoviensis. ISSN 1337-6748. 2018, roč. 12, č. 1, s. 110-128.

OC FUTURUM BRNO. Obchody. futurumbrno.cz. [online]. OC Futurum. [cit. 10. 9. 2018]. Dostupné z: http://www.futurumbrno.cz/obchody-seznam/

OLYMPIA BRNO. Obchody. olympia-centrum.cz. [online]. ECE Projektmanagement GmbH \& Co. KG, 2018. [cit. 13. 9. 2018]. Dostupné z: https://www.olympia-centrum.cz/obchody/vse/.

RAPCO, M. - NEČASOVÁ, A. Expanze na jihu Brna: Avion se rozšíríí, obchody modernizují svoje prodejny. brnensky.denik.cz. [online]. 17. 8. 2016. [cit. 10. 9. 
2018]. Dostupné na internete: https://brnensky.denik.cz/podnikani/expanze-najihu-brna-avion-se-rozsiri-obchody-modernizuji-svoje-prodejny-20160817.html SCOTT, P. 1970/2008. Geography and Retailing. 2nd edition. New Brunswick and London: Aldine Transaction, 1970/2008. 192 s.

SCHIFFMAN, L. G. - KANUK, L. L. 2004. Nákupní chování. Brno: Computer Press, 2004. 695 s. ISBN 8025100944.

SPILKOVÁ, J. 2010. Retail development and Impact Assessment in Czech Republic: Which tools to use? In European Planning Studies. ISSN 1469-5944, 2010, vol. 18, no. 9, pp. 1469-1484.

SPILKOVÁ, J. 2012. Geografie maloobchodu a spotřeby. Praha: Karolinum, 2012. 246 s. ISBN 978-80-246-1951-4.

STATUTÁRNÍ MĚSTO BRNO. Brno Brownfields 2013. [Online]. Brno, 2013. [cit. 16. 9. 2018]. Dostupné na internete: http://www.brno.cz/fileadmin/user_upload/ Podnikatel/Brownfields_2013_CZ.pdf

STOPRO Architects. Avion Shopping Park Brno. stopro.cz. [online]. STOPRO spol. s r.o, 2018. [cit. 18. 9. 2018]. Dostupné na internete: http://www.stopro.cz/projekty/obchodni-centra/avion-shopping-park-brno/.

SUCHÝ, D. Ďalšia vlna nákupných centier. Ktoré otvoria v najbližšom čase? In Reality.TREND.SK. [online]. 28. 4. 2017. [cit. 10. 9. 2018]. Dostupné na internete: https://reality.etrend.sk/komercne-nehnutelnosti/dalsia-vlna-nakupny ch-centier-ktore-otvoria-v-najblizsom-case.html.

SVATOŠOVÁ, L. Výstavba nových obchodních center v Česku stagnuje, na desítku čeká revitalizace. In Mediar.cz. [online]. 24. 6. 2018. [cit. 15. 9. 2018]. Dostupné z: https://www.mediar.cz/vystavba-novych-obchodnich-center-vcesku-stagnuje-na-desitku-ceka-revitalizace/.

SZCZYRBA, Z. 2005. Maloobchod v ČR po roce 1989: Vývoj a trendy se zaměřením na geografickou organizaci. Olomouc: Univerzita Palackého, 2005. 126 s. ISBN 8024412748.

SZCZYRBA, Z. 2002. Shopping Gravity of Large-scale Stores - Example of Terno Olomouc Hypermarket (Contribution to the Study of the Problematic). In Acta Universitatis Palackianae Olomucensis, Geographica. ISSN 1212-2157, 2002, vol. 37, pp. 91-96.

ŠVEDA, M. - KRIŽAN, F. 2012. Prejavy komerčnej suburbanizácie vo vybraných odvetviach hospodárstva v zázemí Bratislavy. In Ekonomický časopis. ISSN 0013-3035, 2012, roč. 60, č. 5, s. 460-481.

TELLER, C. 2008. Shopping streets versus shopping malls-determinants of agglomeration format attractiveness from the consumers' point of view. In The International Review of Retail Distribution and Consumer Research. ISSN 0959-3969, 2008, vol. 18, no. 4, pp. 381-403.

TELLER, C. - ELMS, J. R. 2012. Urban place marketing and retail agglomeration customers. In Journal of Marketing Management. roč. 28, č. 5-6, s.546-567.

TELLER, CH. - ALEXANDER, A. - FLOH, A. 2016. The impact of competition 
and cooperation on the performance of a retail agglomeration and its stores. In Industrial Marketing Management. ISSN 0019-8501, 2016, vol. 52, pp. 6-17. TIMOTHY, D. J. 2005. Shopping Tourism, Retailing, and Leisure. New York: Channel View Publications, 2005. 232 p. ISBN 978-1873150603.

TREMBOŠOVÁ, M. - DUBCOVÁ, A. - KRAMÁREKOVÁ, H. - NAGYOVÁ, L. 2016. Nákupné správanie obyvatelstva města Nitry. Nitra: Slovenská pol'nohospodárska univerzita v Nitre, 2016. $170 \mathrm{~s}$. ISBN 978-80-552-1601-0.

TREMBOŠOVÁ, M. 2010. Vybrané aspekty transformácie maloobchodu v meste Nitra v rokoch 1992-2008. In Geografický časopis. ISSN 0016-7193, 2010, roč. 62, s. 49-73.

TREMBOŠOVÁ, M. - VLAČUHOVÁ, V. - JAKAB, I. 2017. Dostupnost' maloobchodných predajní $\mathrm{v}$ Nitrianskom samosprávnom kraji. In $X X$. mezinárodní kolokvium o regionálních vědách. Brno: Masarykova univerzita, 2017. ISBN 978-80-210-8587-9, s. 582-589.

TREMBOŠOVÁ, M. 2012. Geografické aspekty maloobchodnej siete mesta Nitra. Nitra: UKF v Nitre, 2012. ISBN 978-80-558-0105-6, s. 70-73.

VELKÝ ŠPALÍČEK. Obchody přehled. velkyspalicek.cz. [online]. Generali Velký Špalíček s.r.o. [cit. 10. 9. 2018]. Dostupné z: http://www.velkyspalicek.cz/cz/centrum/obchody-106/.

WOOD, S. - REYNOLDS, J. 2012. Leveraging locational insights within retail store development? Assessing the use of location planners' knowledge in retail marketing. In Geoforum. ISSN 0016-7185, 2012, vol. 43, no. 6, pp. 1076-1087.

\section{ACTORS OF TERRITORIAL DEVELOPMENT IN THE CITY OF BRNO: FOCUSED ON DEVELOPERS OF SIGNIFICANT SHOPPING CENTERS}

\section{Summary}

Shopping zones in city centers were formerly created without prior planning (Crosby et al., 2005), while today's shopping center is (or should be)

a planned purpose. Its size should correspond to the size of purchasing power in the catchment area, the range offered should be sufficiently attractive to attract demand (Teller, 2008; Križan et al., 2016; Teller et al., 2016). In the Czech Republic and other post-socialist countries, the shopping centers were established in the second half of the 1990s, and their real boom arrived in the last decade, which is more than forty years away from economically advanced Europe (Kunc et al., 2012a).

Developer activities in the shopping center segment have also seen a significant spatial, functional and economic shift over the past two decades. The construction of shopping centers does not only take place on the greenfield and on the outskirts of individual cities, but more and more often these projects are located in the inner part of the cities, where revitalization of unused areas takes place. 
There are about 90 shopping centers in the Czech Republic and their construction gradually began in the second half of the 1990s. As far as the main location of these centers is concerned, the construction was mainly in the suburbs of individual cities, mostly on the greenfield. However, the situation started to change and today more than half of the shopping centers in the Czech Republic is built on the territory of the former brownfield. Until 2005, there were only thirteen shopping centers built on previously used territories. Since 2006, the developers' attention has also focused on the inner parts of the cities and previously built areas - thirty-four shopping centers have been established. On the green field, only 10 shopping centers were built. However, when the significance of the areas offered is taken info consideration, the shopping centers built on the green meadow are larger (62\% of the total volume of the rentable area). There are seven shopping centers in Brno and only two of them have been exhibited on an previously used area - Velký Špalíček and Vaňkovka gallery. The remaining shopping centers (Avion Shopping Park, Campus Square, NC Královo Pole, OC Futurum and Olympia Brno) are built on a greenfield and mostly in the suburbs.

In Slovakia, the situation is very similar. Of the fifty-six shopping centers, thirty were built on a greenfield. By the year 2007 there were seventeen shopping centers. On the previously used territories it was only seven shopping centers. As in the Czech Republic, most of them were suburban localities. Since the year 2008, the situation has turned and developers in Slovakia started to see the potential of using brownfields to carry out their projects (2/3 of the projects since the year 2008).

We can say that the building of new shopping centers is gradually slowing down. More often there are plans to expand the existing shopping centers. These changes are related, for example, to the loss of free space and to the entry of new investors into existing shopping centers. In the coming years, we will see whether this trend will actually be confirmed.

\section{Ing. Zdeněk Dvořák}

Ekonomicko-správní fakulta

Masarykova univerzita

Lipová 41a, 60200 Brno

E-mail: dvorak.zdenek@mail.muni.cz 